\title{
Albrecht Ritschl
}

\section{International Capital Movements and the Onset of the Great Depression: Some International Evidence}

\section{Introduction}

Having rational expectations is not always comfortable. Archival historians tell us the story of the international central bankers' meeting at Long Island in 1927, where Benjamin Strong, then governor of the Federal Reserve Bank of New York, predicted that within two years' time, the worst depression in history would set in, the only question being whether it would break out in Germany or in the U.S. (see Link, 1970).

What concerned central bankers at the time was the stabilization of the gold standard in a heavily changed international environment. The pre-war monetary system had largely rested on Britain's unquestioned role as the world leader in capital exports. The flow of revenues generated by these overseas investments helped to stabilize the British balance of payments in times of recession. This, in turn, made it easy for the Bank of England to conduct the "international orchestra" of monetary policies (using a phrase coined by Eichengreen, 1987), even in the absence of large gold reserves of her own.

After World War I, these conditions no longer existed. Britain had used up many of its foreign investments, notably in the U.S., to finance World War I. In addition, large war loans had flowed from the U.S. to Europe. As a consequence, the U.S. converted into the world's largest creditor and would now have to assume the role of the orchestra's conductor. The fundamental difference to pre-war times was that Europe's recovery from the war was not satisfactory. Britain had suffered severely from the deep recession of 1920 and later followed deflationary policies to stabilize its currency at the pre-war parity. France had experienced inflation and turmoil, and by mid-1927 it was not yet clear that Poincare's stabilization of 1926 would be a success. Recovery in Germany had been severely hampered by the hyperinflation in 1922 and 1923 (Eichengreen, 1992). As a result, in 1927 neither Britain nor France had attained their pre-war levels of output per capita, and the same may have been true of Germany (Maddison, 1995). Thus, administering the gold standard was clearly not an easy task. 
To make things worse, much of the stabilization achieved so far seemed artificial and unhealthy. The Dawes Plan of 1924 had brought recovery and stable money back to Germany, at a cost. In order to help Germany to re-stock and modernize its productive apparatus, fresh money had been injected into the German economy. However, instead of putting their house in order and starting to pay out reparations from trade surpluses, the Germans had begun to borrow abroad in almost unlimited quantities. During the Dawes Plan period from 1924 to 1929, Germany paid her reparations entirely on credit, and in addition to that ran massive import surpluses. Germany operated a credit pyramid, a veritable Ponzi scheme; even the interest on existing foreign debt was paid from new credits.

Worries about Germany's reckless foreign borrowing had already appeared in 1925 (Schuker, 1988). In 1926, the president of the Reichsbank, Schacht, started desperate attempts to gain control at least of a portion of public borrowing abroad, but only with limited success (James, 1985). By 1927 , the debt was already so high that Germany was faced with a stark choice: authorities could either deflate the economy abruptly in order to ensure her future capacity to pay, or they would have to keep waiting passively until the bubble burst and the pyramid came crushing down to damage, not only the German economy but the international financial system along with it. No doubt, Mr. Strong had reasons to be worried.

This paper is about the international causation of the Great Depression, centering on the crucial year of 1927. Employing leading indicators for business-cycle activity, I provide evidence that the international depression did not start in the U.S. and that it was probably not caused by an "autonomous" decline in U.S. foreign lending to Europe, as conventional wisdom would have it. As soon as 1927 , there are clear indications of a beginning downturn in the German economy, which came too early to be explained by a contraction of American lending. Both real and financial indicators point downward in Germany one or two years before they do so in the U.S. Cross-examining the results with data for Britain, it appears that the decline in the British economy comes even later.

I am clearly not the first to make this point. In a well-known paper, Temin (1971) argued from an examination of German investment data that there must have been a decline of investment demand before American lending dried up, which would refute the standard hypothesis. Temin's view was challenged by Falkus (1975) and Balderston $(1977,1982)$ on the grounds of measurement problems. Using different data, however, it appears that Temin's point must be re-established.

The rest of this paper is organized as follows. The next section looks at leading business indicators for the German economy, which all show a turning point already in mid-1927. Section III turns to the time profiles of German borrowing and American lending in order to find evidence on the transmission of the business cycle across the two countries. Section IV explores the issue of timing further by looking into turning points in U.S. capital formation. Section V traces the implications for interest rate differentials between Germany, Britain, and the United States. Section VI presents conclusions and implications for further research. 


\section{Turning points in the German business cycle of the 1920s}

Looking at the moving forces of the German inter-war business cycle, we need to distinguish between domestic and foreign components. Considerable parts of Germany's economy, especially the large agricultural sector, were entirely homeoriented. But others, such as manufacturing, were not. Activity in this sector was influenced both by domestic and international demand, which during the interwar period often moved in opposite directions. As a result, industrial production only partly reflected domestic demand trends. This is particularly true of the capital-goods industries. These are interesting to us as their activity also helps to predict investment in the German economy in later periods.

For this industry, we have monthly statistics on domestic and foreign orders, which come from surveys conducted by the German machine builders' association (VDMA) among its members ${ }^{1}$. As can be seen from Figure 1, domestic and foreign orders to German machinery industry followed a very different pattern in the late 1920 s.

Note the marked phase shift between the two series: while foreign orders reached their maximum only in September of 1929, domestic orders peaked al-

Figure 1: Orders to German Machinery Indusry and Tobin's $Q$ in the Berlin Stock Market

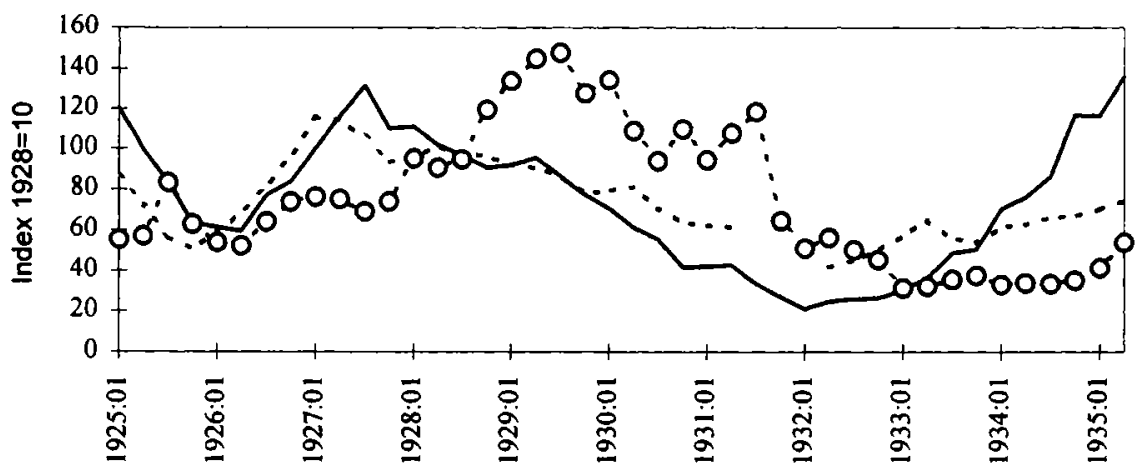

Domestic Orders - 0 - - Foreign Orders - ... Berlin Stock Market Index

Domestic Orders: Wagemann (1935, p. 228, series 66).

Foreign Orders: Wagemann (1935, p. 228, series 67).

Berlin Stock Market Index: Wagemann (1935, p. 115, series 2, deflated by prices of equipment, p. 105, series 27).

1 According to VDMA (1930), its membership represented $90 \%$ of the value added in machine building in 1928. The order series are also in Wagemann (1935). 
ready in August, 1927, and declined thereafter almost without interruption ${ }^{2}$. This means that as far as business expectations were concerned, domestic capital formation was on the decline since mid-1927. Capital installment takes time to build, and therefore, the actual data on investment lagged behind. Here, we see that between 1927 and 1929 there is no clear tendency. This explains much of the debate about Temin's (1971) data. If one looks at realized investment rates only, the existence of a turning point of 1927 is not so clear, as it only can be affirmed that an investment boom came to an end, albeit still at a high level of activity. Only if we look at an early indicator of domestic investment demand, we can spot the turning point correctly.

There is further corroborating evidence. In Figure 1 the series of domestic orders is also plotted against the price-adjusted Berlin stock market index (or Tobin's q). Both series peak sometime in 1927 and decline thereafter. It is noteworthy how well the stock market data and domestic machinery orders correlate with one another ${ }^{3}$. In fact, the stock market appears to be a leading indicator for machinery orders, as predicted by economic theory ${ }^{4}$.

The tight correlation between the stock market index and the domestic machinery order series is evidence against a bubble in the 1927 stock market. There existed fundamentals in the German economy which supported the previous stock market increases, and when the stock market declined, these fundamentals went down as well. Apparently, some fundamental change occurred in the German economy in 1927 which induced investors to become bearish about stocks and real capital investments as well.

If trouble was ahead for the German economy and if investors expected that, this should also be visible in the bond markets. A concept that has attracted increasing attention in recent years is the term structure of interest rates. Under normal business conditions, interest rates are higher in the long run. However, when investors expect a deflationary shock to occur, the term structure, or difference between long- and short-term interest rates, may become smaller or even negative. The term structure shown in Figure 2 provides an example of just this effect, and once again, the recessive impulse we are looking for is visible in 1927.

Unfortunately, our data do not permit us to focus more closely on the time horizon at which investors expected the deflationary shock to occur. Ideally, we should have interest rates on bonds of different maturity to be able to construct a yield curve over a time span of several years. This we do not have. The short-term

2 From April 1928 to August 1932, domestic orders in each month are lower than in the respective month of the preceding year. The only exception is April 1929; otherwise the decline is uninterrupted.

3 The tight correlation between these two series was first noted by Donner (1934). We note in passing that domestic demand follows a very similar pattern at the time. All series come from Wagemann (1935).

4 The stock market data shown here are stock prices divided by machinery prices, which is an indicator for Tobin's $q$, the relative price of existing and new equipment. If this goes up, investment should rise, and vice versa. The seminal paper on this is Hayashi (1982). 
Figure 2: The Term Structure of Interest Rates, Germany 1926-1935

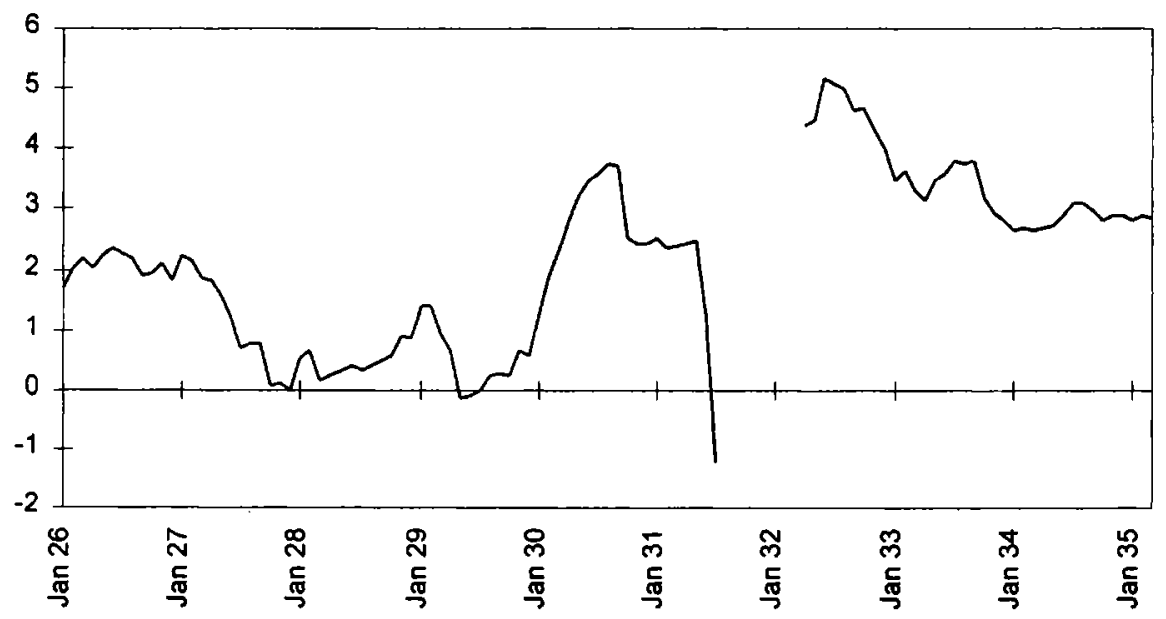

Term Structure: NBER Macrohistory database, series 13028 (yields on gold bonds), series m13018 (Berlin private discount rate).

interest rates are for three-monthly paper, while the long-term rates are on longterm gold bonds with unspecified maturity. However, even in these imperfect data we do see a dramatic deterioration in the term structure in 1927, two years before deflation actually set in. We note that, if investors predicted the depression correctly, they believed it to be short-lived: the span between the collapse of the term structure in mid-1927 and its even more dramatic recovery is 9 quarters. If we take this literally, investors predicted a slump of slightly more than two years - which means they underestimated the length of the deflation period by exactly one year. (It is probably not accidental that the term structure recovers at the beginning of 1930. Once the slump had visibly set in also in the international scene, it was not entirely extraneous to believe that conditions would improve within reasonable time.)

The evidence on the term structure also permits conclusions regarding the importance of international capital movements. Conventional wisdom at the end of the Golden Twenties maintains that the downturn in the European economies was caused by dwindling American capital exports, which in turn is held to have caused investment to fall. If this was the case, investment should have been choked off by rising interest rates instead of deteriorating through worsening expectations and falling domestic demand. This, in turn, should have caused long-term interest rates to rise relative to short-term rates. Evidently, the converse holds true. If investment rates were really brought down by high interest rates, we should see the term structure spread out instead of becoming more compressed. Hence, we must conclude that the transmission must have gone from falling in- 
vestment demand to falling relative interest rates at the long-term end of the yield curve, not the other way round.

\section{German capital imports and U.S. capital exports}

We may also compare German capital imports and U.S. capital exports directly. Following Fleisig (1970), Kindleberger (1973) concluded that the upcoming stock market boom choked off U.S. foreign lending. If the German credit expansion of the 1920s was merely a passive reflection of American lending, its time profile and term structure should more or less follow the U.S. data. Data in Figure 3 provide data on German net capital imports during the decade following the end of hyperinflation. Once again, we observe a peak in 1927, followed by a collapse from 1928 to 1929. Note also that much of Germany's foreign borrowing was short-term, to be converted into long-term loans by German banks at home. It was precisely this "hot money" end of the market which collapsed first.

If we now compare this to the U.S. data on capital exports (Figure 4), we find a number of markedly contrasting features. First, U.S. capital exports peaked only in 1928, one year after German capital imports. Second, we do observe a small decline in short-term capital exports, which however is too little to explain the collapse of German short-term capital imports in the same period. Third, U.S. direct investment abroad continued to increase in 1929 and went down only in 1930, while German long-term capital imports were practically dead already in 1929 (the blip in 1930 is caused by the Young loan for German reparations, designed to postpone Germany's foreign debt crisis by one year).

Figure 3: German Capital Imports, 1924-1935

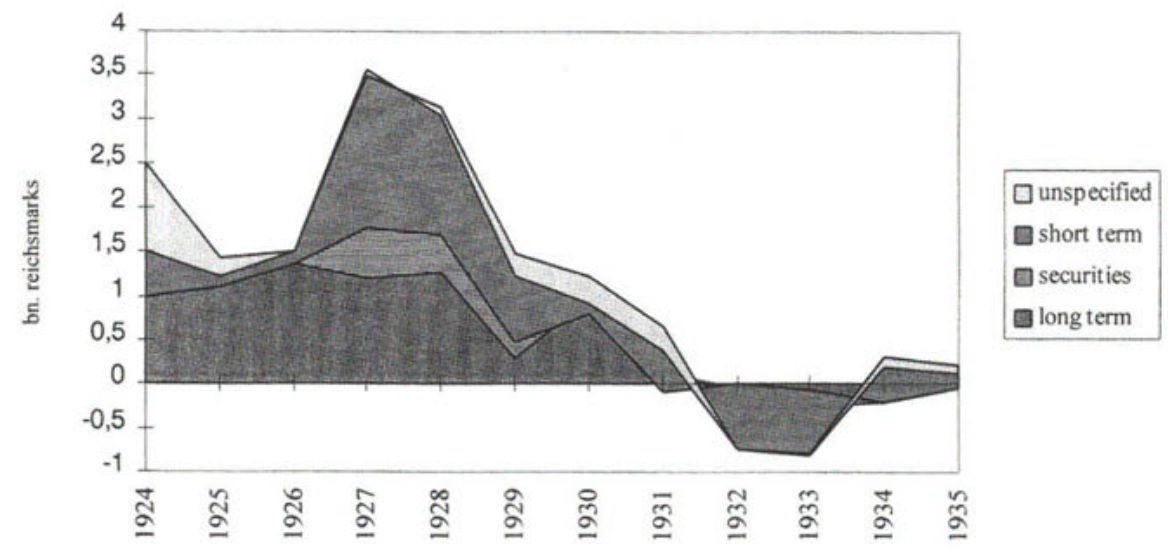

German net capital imports: Bundesbank (1976, p. 328). 
Figure 4: U.S. Capital Exports (US funds only), 1924-1935

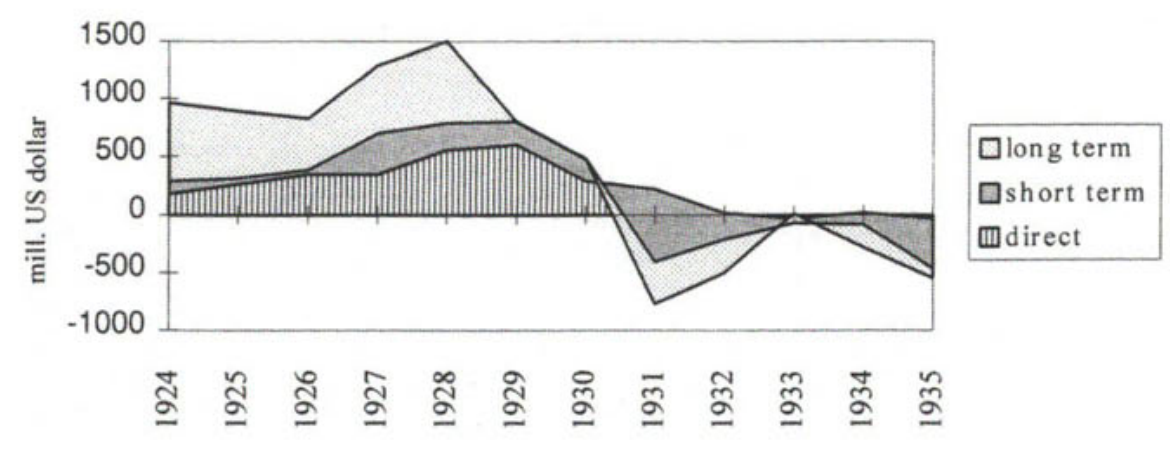

U.S. net capital exports (U.S. funds): Dept. of Commerce (1972).

It seems safe to conclude from these discrepancies that there must be more to the decline in German capital imports than just faltering U.S. capital exports: the decline in German capital imports comes too early, and it occurs at the wrong end of the term structure.

This observation squares well with the German interest data we examined in the previous section. Had there been a sudden lack of loanable funds for long-term investment projects, as Kindleberger (1973) and many others have suggested from U.S. data, we would have seen an increase in German long-term interest rates relative to short-term rates. At the same time, long-term capital flows between the U.S. and Germany would have had to go down simultaneously. Instead, in 1927 and 1928 we see a sharp decline in German short-term borrowing which has no counterpart in U.S. short-term lending, and German short-term interest rates go up while long-term rates remain stable: Germany had become an unsafe place for hot money once its stock market boom was over, even before the New York stock market really took off.

Last in this section, let the argument be carried still further. Traditionally, economic historians are educated to think of the United States as the capital-exporting giant whose cough would cause pneumonia in the rest of the world. As the above figures bear out, Germany at that time was not exactly a small economy either: its net capital imports after 1924 oscillated between 40 and $65 \%$ of America's own capital exports. They were even higher relative to U.S. figures if the movements of all funds and not just U.S. ones are included in the latter. Figure 5 provides a synopsis of German and U.S. net capital imports.

As the figure bears out, Germany's capital imports during the 1920 s are actually often larger than America's capital exports. The average from 1925 to 1929 is $117 \%$ of U.S. net capital exports, including funds of foreign origin in the latter.

There is yet another observation to be made in Figure 5. With the movements of foreign funds included, the U.S. capital balance looks notably less business-cycle 
Figure 5: Total Capital Imports, US and Germany, 1924-1935

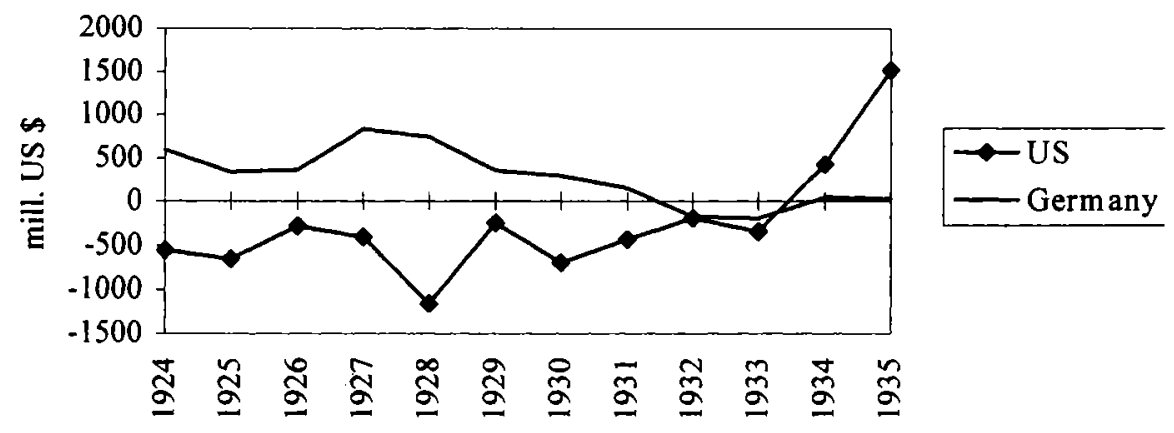

U.S. net capital exports (foreign funds): Dept. of Commerce (1972).

driven than before, and also less so than the German figures. Even in 1931, U.S. net capital exports are still larger than in 1927.

With all these elements in place, there seems to be little room for the traditional capital-flow hypothesis: apparently, Temin (1971) was right. There is much in the German data that points to a domestic-driven business downturn already by 1927 , and it is hard to see how the impulse for this should have come from abroad, especially from the U.S., where lending of U.S. funds declines too late and aggregate net lending exhibits no clear trend at all.

Given the magnitudes involved in Germany's capital imports, the question of the direction of causality is not a trivial one. One may even wonder if Germany's balance-of-payments troubles could possibly have had their own international repercussions.

\section{Turning points in the business cycle in the U.S. and Britain}

In the following, we do not endeavor to make a contribution to the debate about whether or not the New York stock market boom prior to October, 1929 was a bubble. We only are interested in tracing major fundamentals in the U.S. economy to find turning points and identify their timing. The obvious first candidate are corporate dividends. From a self-constructed dividend series for the Dow Jones listed companies, White (1990) concluded that from 1928 on, the index systematically outperformed dividend growth, which indeed would indicate a bubble. However, what is notable is that dividends continued to grow; there are few signs of a downturn in the data before the end of 1929. Nevertheless, White (1990) concludes from his analysis that managers apparently did not share the enthusiasm of 
the public, hence the discrepancy between stock market and dividend growth must have been a bubble.

Of course, dividend growth does not need to match the growth in the value of equity, at least in the short run. But if a change in dividend policies occurred between 1926 and 1927, an explanation is needed. For this, we repeat the exercise from section II above in which a suitably deflated version of the stock market index was compared to machinery output (or, in that case, new domestic orders). This way, we may determine if managers shared the expectations of the financial market. If they did, Tobin's $q$ theory of investment would advise them to adjust their capital stock upward by the same measure. If they didn't and remained pessimistic instead, growth of machinery output should fall short of stock market performance.

We saw above that for Germany, there was indeed a tight correlation between the stock market and investment activity, and that the stock market actually predicted how much would appear in next month's order books. Data for the U.S. economy are shown in Figure 6.

Figure 6 tells us two things: first, the order of magnitude of the changes in investment demand and stock market value is the same. If there was a bubble in the late 1920s, it extended to managers' expectations as well and was not confined to financial markets. Second, in contrast to the German case, the investment climate in 1928 was consistently better than in 1927 . Orders of new capital goods only stop growing in the spring of 1929 ; it is the very last part of the stock market boom which is no longer supported by the fundamentals of the order series.

Figure 6: Orders of US Machine Tools and Tobin's Q in the Dow Jones Stock Market Index, 1921-35

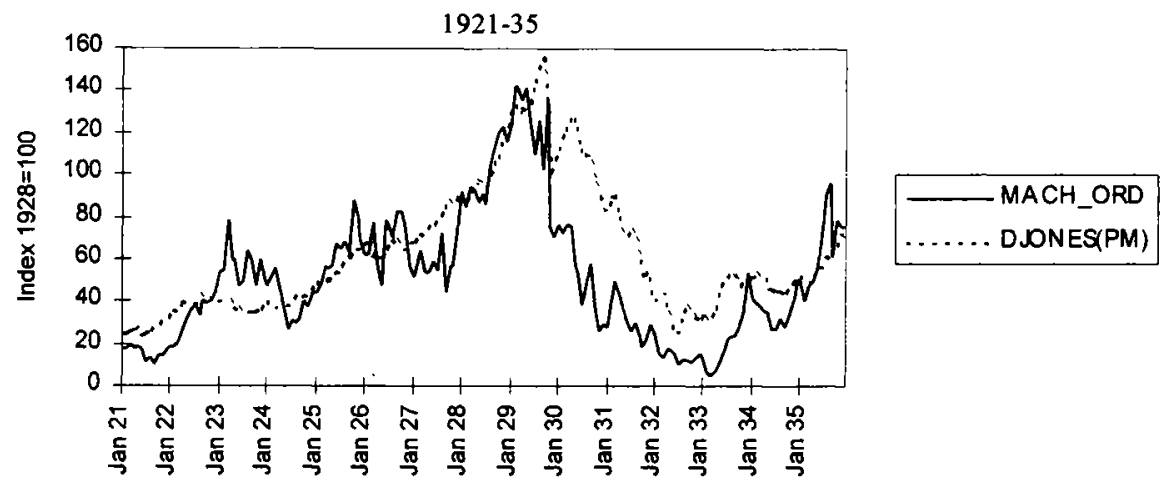

U.S. machine orders: NBER Macrohistory database, series 06029 (shipments of machine tools).

Stock market index: NBER Macrohistory database, series 11009 (Dow Jones Index), series 04066 (prices of metal products). 
Note that there does not seem to be a very clear lead-lag pattern between the two series in Figure 6; however, at the onset of the depression, machinery orders fall earlier and deeper than the stock market index. In sum, there are no signs of a depression in U.S. investment and the stock market until well into 1929: by the time the investment boom came to an end, investment orders and the stock market in Germany had already fallen by some $25 \%$.

\section{Interest Rates and Term Structures: the Transatlantic Perspective}

If the major European players in the pre-depression credit gamble experienced difficulties in borrowing from the U.S., this should be reflected in interest rate differentials with respect to the U.S. As data in Figure 7 below bear out, long-term interest rates in Britain were consistently higher than in the U.S. for the whole period of Britain's adherence to the gold standard. One might conclude that markets did not reward Britain's "good housekeeping" with a seal of approval, as Bordo/ Edelstein/ Rockoff (1998) would have it. On the contrary, lacking ability to sustain foreign exchange equilibrium without credit restrictions was apparently punished by international markets, if only slightly.

Figure 7: Long-Term Interest Rates Differentials vis-à-vis the US

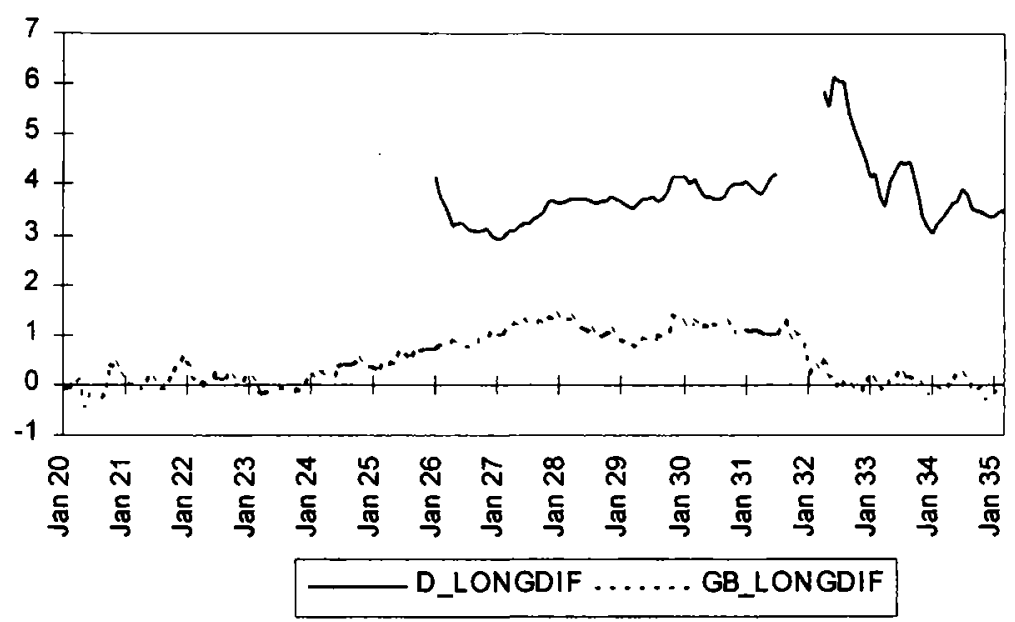

Long-term Interest Rate Differential, Germany/U.S.: NBER Macrohistory database, series 13028 (yields on gold bonds), series 13033 (yields on United States eight-year bonds).

Long-term Interest Rate Differential, Britain/U.S.: NBER Macrohistory database, series 13041 (yields on UK consols), series 13033 (yields on United States eight-year bonds). 
The real action is no doubt in the German data. German bonds commanded a premium over U.S. bonds that never fell below three percentage points and that increased notably during 1927. In 1928 when U.S. capital exports reached their maximum, German long-term interest rates were higher and German capital imports lower than in the previous year. During early 1929 when U.S. lending dropped dramatically from its 1928 peak (Fleisig, 1970), we see no upward response in Germany's and Britain's interest rates. Note that in contrast, Britain's interest rates went down relative to the U.S. in the same period. Only in late 1929 do interest rate differentials widen. Apparently, there was more to the transatlantic capital market than just dwindling U.S. capital exports.

The evidence obtained in this section may be complemented with data on the term structure of interest rates across major countries. In each of the three countries, we compare the interest on long-term bonds with yields on three-monthly paper (Figure 8).

Data for the years of 1927 to 1929 exhibit a striking regional pattern: the yield curve collapsed first in Germany (late 1927), half a year later in the U.S. (early 1928), and only in early 1929 did the change affect Britain. Unfortunately, data quality does not permit us to compare levels of the term structure directly across

Figure 8: The Term Structure of Interes Rates Long-Terms Bonds vs. Three-Monthly Paper

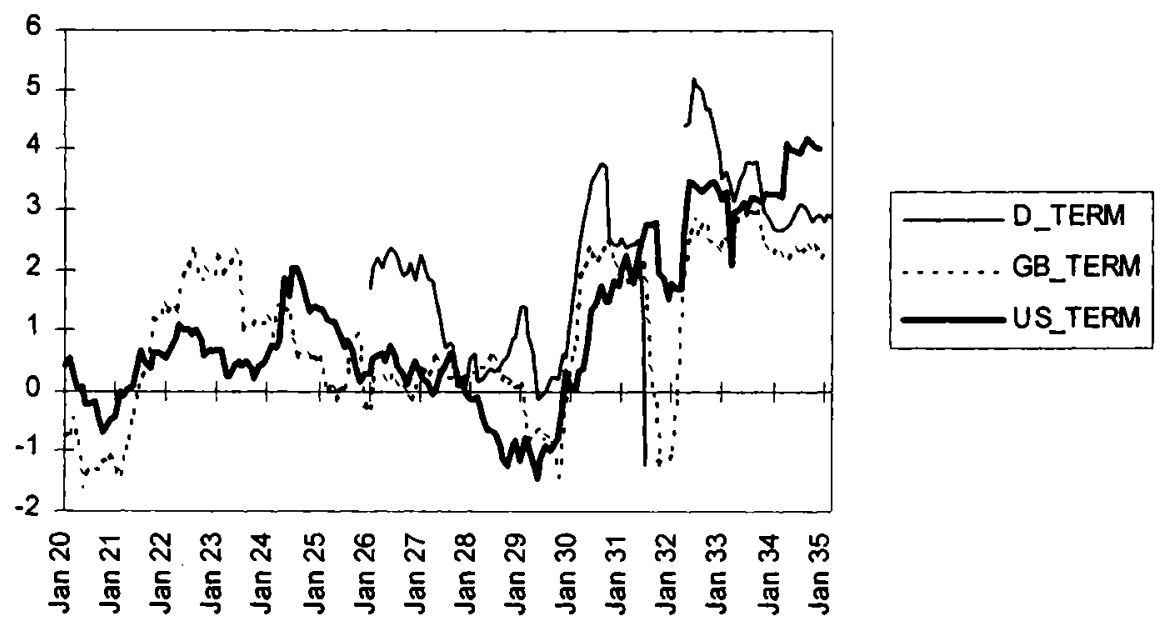

German term structure: see Figure 2.

British term structure: NBER Macrohistory database, series 13041 (yields on UK consols), series 13016 (London open market rates of discount).

U.S. term structure: NBER Macrohistory database, series 13033 (yields on United States eight-year bonds), 13029 (yields on short-term Treasury notes, certificates, and bills). 
countries ${ }^{5}$. However, a clear temporal pattern emerges which is consistent with the findings in Section II above: the writing on the wall appeared first in Germany, not in the U.S.

We do not want to enter into the debate on whether deflation in the U.S. was anticipated at the onset of the depression ${ }^{6}$. Lacking more detailed information on the yield curve, little can be said about the time horizons at which investors in the bond market expected deflationary turnarounds. However, the deterioration of expectations we observe is a quick one. Already by mid-1928, a trough is reached. Thus, deflationary expectations did exist in the U.S. bond market well before the depression set in. However, if we look only at the period where the term structure is inverted, neither the extension of the deflationary period nor the depth of deflation seem to be well anticipated by the market.

We might alternatively argue that the flattening of the yield curve in 1924/25 already predicts the depression. Given that the peak occurs in 1924, the peak of activity in $1928 / 29$ would be predicted with a lead of $4 \frac{1}{2}$ years. Consequently, assuming the same lead from mid-1928 to late 1929 would predict the trough of the depression to occur between early 1933 and mid-1934, with subsequent sharp recovery thereafter. This speculation may, however, be too daring. Clearly, more research on this issue is needed.

\section{Conclusions and Implications}

A reexamination of international capital movements at the onset of the Great Depression leads to new results which may shed light on the causes and the spread of the slump. During the second half of the 1920s, Germany's net capital imports were on average larger than American capital exports. This paper has studied the term structure and the timing of these capital movements to draw conclusions about the possible causes of the collapse in international credit relations prior to the Great Depression. To find out whether there were domestic factors behind these credit flows, we also identified turning points in the domestic business cycles of both countries.

In Germany, domestic investment demand, the stock market, and foreign borrowing start to decline in 1927 and continue to fall almost without interruption through mid-1932. As U.S. lending continues to grow spectacularly through mid-

5 The reason is that both the British and German short-term bills whose yields we included were risk-bearing, while in the U.S. we chose short-term treasury bonds. Repeating the exercise with risk-bearing commercial paper for the U.S., the results are basically unchanged; the collapse of the U.S. yield curve is postponed somewhat further into 1928.

6 On this, see Cecchetti (1992) with evidence in favor and Hamilton (1992) with evidence against predictability of the deflation process. Given our results on the yield curve, we would cautiously lean toward the first position. 
1928 , this decline in Germany comes too early to be explained by reduced supply of U.S. credit.

Our results lend new credibility to Temin's (1971) hypothesis of an autonomous beginning of the depression in Germany in 1927. The fall in German borrowing abroad was apparently induced by factors pertaining to the domestic economy. Uncertainty over the future reparation burden and the German policy of paying reparations on credit under the Dawes Plan increased the risk of lending to domestic and international investors in that country. Buoyant export demand and the injection of fresh money under the Young Plan would postpone the hour of reckoning, but the unsustainable credit expansion of the German economy was an issue of public debate as early as 1927.

In contrast, market fundamentals in the U.S. continued to look favorable. The stock market boom was fully supported by rising investment demand up until early 1929. The only disturbing evidence we found came from the bond market. Examining the term structure of interest rates across countries, we find that expectations of a business downturn become visible in Germany already in the second half of 1927, when the German yield curve becomes compressed or even inverted. These deflationary expectations carry over to the U.S. in the first half of 1928, when the yield curve suddenly inverts itself, while the British bond market is affected only in early 1929 .

These results have their possible implication for our understanding of the interwar gold standard. While traditionally, we have been led to think of a monetary transmission of deflationary shocks from the U.S. to the rest of the world, the evidence presented in this paper suggests that in the late 1920s, the main deflationary impulse originated in Germany. More research is needed to trace the interactions between bond markets and money markets prior to the Great Depression at an international level.

\section{References}

Balderston, T., The German Business Cycle in the 1920s: A Comment, in: Economic History Review 30 (1977) 159-161

Balderston, T., The Origins of Economic Instability in Germany, 1924-1930. Market Forces versus Economic Policy, in: Vierteljahrschrift für Sozial- und Wirtschaftsgeschichte 69 (1982) 488-514

Bordo, M. / Edelstein, M. / Rockoff, H., Was Adherence to the Gold Standard a 'Good Housekeeping Seal of Approval' during the Interwar Period?, mimeo (1998)

Cecchetti, S., Prices During the Great Depression: Was the Deflation of 1930-1932 Really Unanticipated?, in: American Economic Review 82 (1992) 141-56

Donner, O., Die Kursbildung am Aktienmarkt. Grundlagen zur Konjunkturbeobachtung an den Effektenmärkten, in: Vierteljahreshefte zur Konjunkturforschung, Sonderheft 34 (1934)

Eichengreen, B., Conducting the International Orchestra: Bank of England Leadership under the Classical Gold Standard, 1880-1913, in: Journal of International Money and Finance 6 (1987) 5-29 
Albrecht Ritschl

Eichengreen, B., Golden Fetters. The Gold Standard and the Great Depression, 1919-1939 (Oxford 1992)

Falkus, M. E., The German Business Cycle in the 1920s, in: Economic History Review 28 (1975) 451-65

Hamilton, J., Was the Deflation During the Great Depression Anticipated? Evidence from the Commodity Futures Market, in: American Economic Review 82 (1992) 157-78

Hayashi, F, Tobin's Marginal $\mathrm{q}$ and Average q: A Neoclassical Interpretation, in: Econometrica 50 (1982) 213-224

Kindleberger, C. P., The World in Depression, 1929-1939 (Berkeley 1973)

Link, W., Die amerikanische Stabilisierungspolitik in Deutschland 1921-32 (Düsseldorf 1970)

Maddison, A., Monitoring the World Economy, 1820-1992 (Paris 1995)

Schuker, S., American Reparations to Germany, 1924-1933 (Princeton Studies in International Finance 61) (Princeton 1988)

Temin, $P$., The Beginning of the Great Depression in Germany, in: Economic History Review 24 (1971) 240-248

VDMA, Statistisches Handbuch für die deutsche Maschinenindustrie (Berlin 1930)

Wagemann, E. (ed.), Konjunkturstatistisches Handbuch 1936 (Hamburg 1935)

White, E., The Stock Market Boom and Crash of 1929 Revisited, in: Journal of Economic Perspectives 4 (1990) 67-83 